\title{
NEW DATA ON THE XANTHOLININI FROM THE ORIENTAL REGION. 43. NEW SPECIES AND NEW RECORDS (COLEOPTERA STAPHYLINIDAE) $273^{\text {th }}$ Contribution to the knowledge of the Staphylinidae
}

(*) Museo di Storia Naturale dell'Università di Firenze, sezione di Zoologia "La Specola"- Via Romana 17, I-50125 Firenze, Italy; e-mail arnaldo.bordoni@fastewbnet.it

Bordoni A. - New data on the Xantholinini from the Oriental Region. 43. New species and new records (Coleoptera Staphylinidae). $273^{\text {th }}$ Contribution to the knowledge of the Staphylinidae

The following new species for the listed countries are described and their diagnostic structures are figured: Pachycorynus insularis sp. n. (Sri Lanka), Metolinus sibayak sp. n. (Sumatra), Erymus tujuh sp. n. (Sumatra), Atopolinus tanarata sp. n. (Malaysia), and Atopolinus nigellus sp. n. (Vietnam). The following species are new records for the named countries: Zeteotomus bedugulensis Bordoni, 2002 (Java), Spaniolinus rubidus Bordoni, 2002 (Malaysia), Thyreocephalus annulatus (Fauvel, 1895) (Tioman Isl., Malaysia), Phacophallus japonicus (Cameron, 1933) (Cambodia), Emathidis humerosa (Bernhauer, 1923) (Vietnam), and Atopolinus ovaliceps (Scheerpeltz, 1965) (Vietnam). New distribution records are given for several species.

Key Words: Coleoptera, Staphylinidae, Xantholinini, new species, Pachycorynus, Metolinus, Erymus, Atopolinus, new records, Oriental Region.

\section{INTRODUCTION}

Since the revision of the Xantholinini of the Oriental Region (BORDONI, 2002), I have dedicated 42 contributions to the knowledge of this tribe from this area. In this contribution I give the results of the study of numerous specimens received from some institutions and private collections. In these pages I describe five new species from various countries and list new records.

\section{Acronyms}

cB ........ coll. Bordoni, Firenze, Italy

cH........ coll. Hayashi, Kawanishi, Japan

cI .......... coll. Ito, Kyoto, Japan

cS......... coll. Schülke, Berlin, Germany

ISBD ..... Institute of Systematic Biology, Daugavpils, Latvia

MMUE... Manchester Museum, Manchester, UK

MNB ..... Naturhistorisches Museum, Berlin, Germany

MZF ...... Museo Zoologico "La Specola", Firenze, Italy

NHMB ... Naturhistorisches Museum, Basel, Switzerland

NMW .... Naturhistorisches Museum, Wien, Austria

\section{TAXONOMY}

(in systematic order)

Pachycorynus balux Bordoni, 2002

Material examined - N Sumatra, Brastagi, Gn. Sibayak, 1450-1900 m, Bocak \& Bocakova 19-23.II.1991, 1 ex. (NHMB), 1 ex. (cB).

DistribUtion - The species seems endemic to Sumatra (Bordoni, 2002). This is the first record since the description of the species.
Pachycorynus alseus Bordoni, 2002

Material examined - Sumatra, Si Rambè, E. Modigliani XII.1890-III.1891, 1 ex. (NMW).

Distribution - The species seems endemic to Sumatra (BordOnI, 2002). This is the first record since the description of the species.

REMARKS - The specimen bears the labels "trigonocephalus Epp." (handwritten by Eppelsheim), "c. Eppelsh./ Steind. d.", "Typus" (printed on red label) (in litt.).

Pachycorynus dimidiatus Motschulsky, 1858

Material eXAmined - Engano, Malaconni, Modigliani 1891, 1 ex. (NMQ); Nias, Jordan, 10 exx. (NMW); Myanmar, Bhamò, Fea VIII.1885, 2 exx. (NMW).

DISTRIBUTION - The species is very widespread in the Oriental Region, from India to Borneo and Philippines (BORDONI, 2002).

\section{Pachycorynus selangorensis Cameron, 1936}

Material eXAmined - W Malaysia, Pahang, Cameron Highl., Tanah Rata, 1500-1700 m, 04.28N, 101.21E, R. \& H. Fouquè 8-17.VII.2004, $1 \hat{\jmath}(\mathrm{cH})$.

Distribution - The species is known only from Malaysia (BORDONI, 2002; 2006). 


\section{Pachycorynus insularis sp. n.}

\section{MATERIAL EXAMINED - Holotype $\overparen{\delta}$ : Ceylan (NMW).}

DESCRIPTION - Length of body $4.5 \mathrm{~mm}$; from anterior margin of head to posterior margin of elytra: $2.5 \mathrm{~mm}$. Body yellowish-brown. Head sub-quadrangular, moderately dilated anteriad, with narrowly rounded posterior angles. Eyes small, scarcely protruding. Surface of head with lateral groove, polygonal micro-reticulation and scattered punctation. Pronotum narrower than head, as long as it, dilated anteriad. Surface with dorsal series of 6 punctures and lateral series of 3 anterior punctures. Elytra longer and wider than pronotum, dilated posteriad, with marked humeral angles. Surface with fine, superficial punctation, arranged in numerous series. Abdomen with transverse micro-striation and fine, sparse punctation.
Tergite and sternite of the male genital segment as in Fig. I, 1-2. Aedeagus (Fig. I, 3) $0.33 \mathrm{~mm}$ long, small, partially membranous, with short and narrow parameres; inner sac apparently not visible; distal sclerite very small.

ETYMOLOGY - The specific epithet is the Latin insularis$e$ (insular).

Distribution - The species is known only from Sri Lanka.

REMARKS - The specimen, labelled "Holisomorphus/ ceylanensis Kr./ Typ. Ceylan/ ded. Kraatz", "Cotypus” (on red label), "c. Eppelsh./ Steind. d.", was part of the series of Holisomorphus ceylanensis Kraatz, 1859, synonym of Pachycorynus dimidiatus Mot., from which the new species differs by smaller size, lighter color and aedeagus.

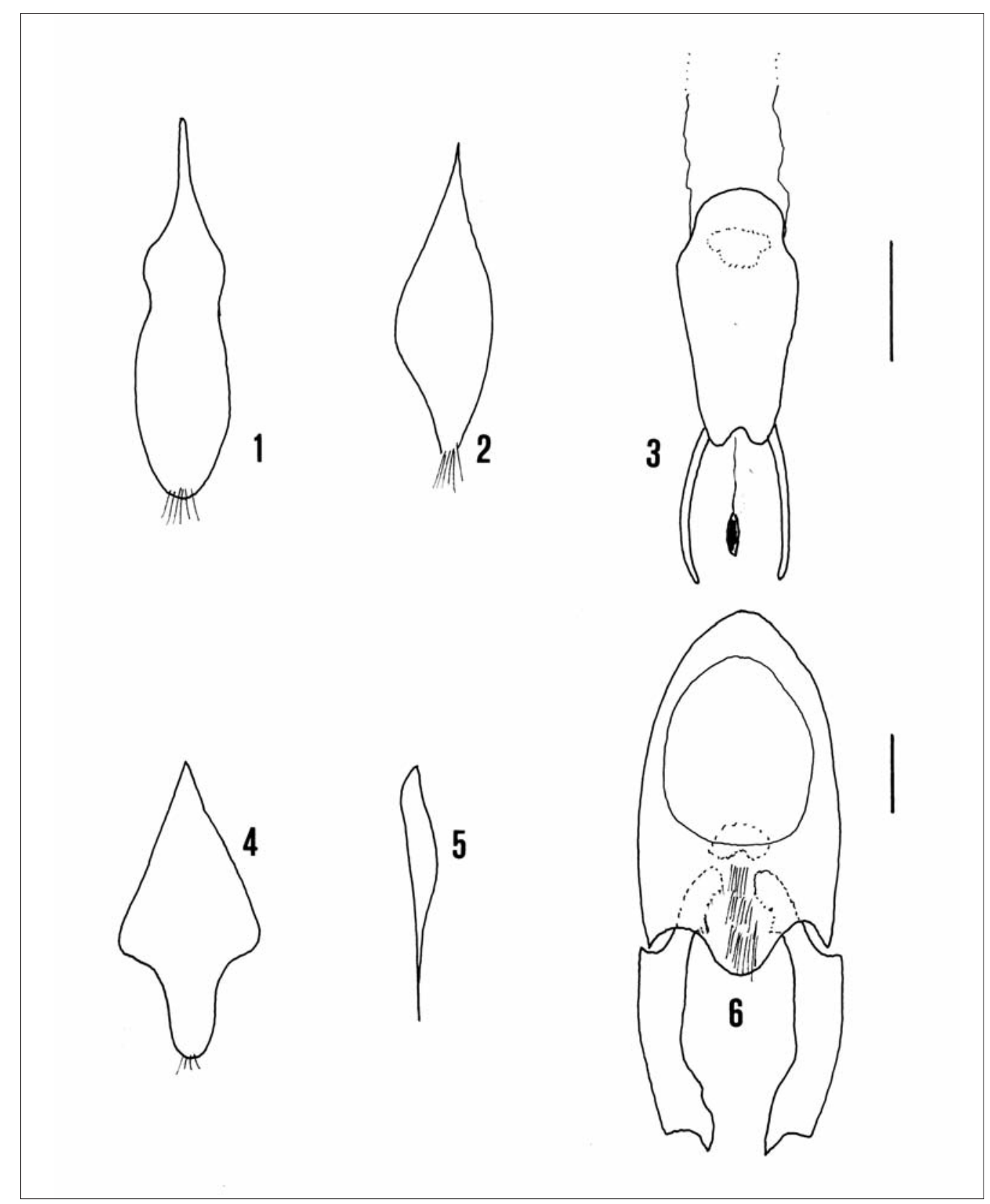

Fig. I - 1. Tergite, 2. sternite, 3. distal portion of aedeagus of Pachycorynus insularis sp. n.; 4. tergite of the male genital segment, 5. sternite of the same, 6. aedeagus of Erymus tujuh sp. n. (bar scale: $0.1 \mathrm{~mm}$ ). 
Neoxantholinus piraticus Bordoni, 2002

Material eXamined - W Malaysia, Pahang, Cameron Highl., Tanah Rata, 1500-1700 m, 04.28N, 101.21E, R. \& H. Fouquè 8-17.VII.2004, 1 ex. (cH).

Distribution - The species is known from Malaysia and Sumatra (Bordoni, 2002). This is the first record since the description of the species.

\section{Zeteotomus bedugulensis Bordoni, 2002}

Material eXAmined - E Java, Ijen Nat. Park, $12 \mathrm{~km} \mathrm{~W}$ Sodong, 1000 m, loc. coll. V.2011, 1 ex. (cB).

Distribution - This species is known only from Bali (Bordoni, 2002). New record for Java. This is the first record since the description of the species.

\section{Spaniolinus rubidus Bordoni, 2002}

Material examined - W Malaysia, Pahang, Cameron Highl., Tanah Rata, H. Ashida 8.VIII.1997, 1 ex. (cI).

DistRIBUTION - The species was known only from the Philippines (Bordoni, 2002). New record for Malaysia.

\section{Achmonia laosiana Bordoni, 2016}

Material eXAmined - Vietnam, Hoalg Lien Son, Sa Pa, P. Pacholatko 11-15.V.1990, 1 ex. (cB).

Distribution - The species was described from NE Laos and cited from Vietnam (BORDONI, 2017) and Thailand (BORDONI, 2017a).

\section{Thyreocephalus tonkinensis Bordoni, 2002}

MATERIAL EXAMINED - "Indochine", Vanyen, Riv. Voire, Dussault 192-1924, 1 ex. (NHMB).

Distribution - The species is known from Vietnam, Laos and South China (Bordoni, 2002), Thailand (BORDONI, 2017a).

\section{Thyreocephalus annulatus (Fauvel, 1895)}

MAterial EXAMINED - Malaysia, Tioman Isl., Kampong Tekek, R. Hergovits 4-26.XI.2000, 8 exx. (cH); same data, K. Juara, 400 m, 2.48N, 104.11E, Dembicky \& Pacholatko 9.III.1998, 1 ex. (NHMB); Malaysia, Benom Mts, $15 \mathrm{~km}$ E Kampong Dong, 700 m, 3.53N, 102.01E, Dembicky \& Pacholatko 1.IV.1998, 4 exx. (NHMB), 1 ex. (cB); Malaysia, W Perak, 25 km NE Ipoh, 1200 m, Banjaran Titi Wangsa Mts, Korbu, P. Pacholatko 11-16.I.1999, 1 ex. (cI); S Sumatra, SW coast Ranau Lake, 1200 m, Bolm 14.VI.2001, 2 exx. (NHMB); Sumatra, Sumater Utara prov., Tangkahan, $100 \mathrm{~m}, 02^{\circ} 400^{\prime} 59^{\prime}$ N , 098 04'22' E, R. Cibulskis 5.II.2011, 2 exx. (ISBD); same data, Gunung Leuser Nat. Park, 100 m, 0340'59'N, 09804'22'E, R. Cibulskis 4.II.2011, 1 ex. (ISBD).
Distribution - From Myanmar to Lombok (Bordoni, 2002), Sulawesi and New Guinea (Bordoni, 2012). New record from Tioman Island.

\section{Thyreocephalus lorquini (Fauvel, 1877)}

Material examined - Celebes, Bowonglangi, Drs. Sarasin, 5 exx. (NHMB), 2 exx. (cB); N Celebes, Mararang, Drs. Sarasin, 2 exx. (NHMB).

Distribution - Sulawesi, Moluccas (Bordoni, 2002), Australia (Bordoni, 2015), New Guinea (Bordoni, 2010).

Thyreocephalus indicus (Fauvel, 1895)

MATERIAl EXAMINED - Malaysia, Kedambe prov., 400 m, 0340'48'”N, 097³9'40'”E, R. Cibulskis, V. Vahrusevs \& D. Volkov 16.I.2011, 1 ex. (ISND).

DistRIBUTION - Indo-Malay subregion (BORDONI, 2002).

Thyreocephalus perakensis Bordoni, 2004

Material eXAmined - Malaysia, Benom Mts, $15 \mathrm{~km} 15$ km E Kampong Dong, 700 m, 3.53N, 102.01E, Dembicky \& Pacholatko 1.IV.1998, 1 ex. (NHMB), 1 ex. (cB); Malaysia, Pahang. Cameron Highl., Tanah Rata, 15001700 m, P. Pacholatko 23-31.I.2003, 1 ex. (NHMB).

Distribution - The species was described from Malaysia (Perak). These are the first records since the description of the species.

\section{Thyreocephalus nigricantis Bordoni, 2009}

Material EXAMined - Malaysia, Benom Mts, $15 \mathrm{~km} 15$ km E Kampong Dong, 700 m, 3.53N, 102.01E, Dembicky \& Pacholatko 1.IV.1998, 1 ex. (NHMB), 1 ex. (cB).

Distribution - This species was described from Malaysia (Johor).

\section{Metolinus modiglianii Bordoni, 2002}

MAterial EXAmined - N Sumatra, Brastagi, 1450-1900 m, Bocak \& Bocakova 19-23.II.1991, 2 exx. (NHMB), 1 ex. (cB).

Distribution - The species is known from Sumatra (Bordoni, 2002), Java and Mentawei (Bordoni, 2009a).

\section{Metolinus perakensis (Cameron, 1950)}

Material examined - N Sumatra, Brastagi, Gn. Sibayak, 1450-1900 m, Bocak \& Bocakova 19-23.II.1991, 1 ऽ (NHMB).

Distribution - This specie is known from Sumatra and Malaysia (BORDONI, 2002). 


\section{Metolinus sibayak sp. n.}

Material EXAMINed - Holotype $\odot$ : N Sumatra, Brastagi, Gn. Sibayak, 1450-1900 m, Bocak \& Bocakova 1927.II.1991 (NHMB); paratype: same data, 1 \& (cB).

DESCRIPTION - Length of body $4.3 \mathrm{~mm}$; from anterior margin of head to posterior margin of elytra: $2.2 \mathrm{~mm}$. Body shiny, brownish-black, with posterior margin of elytra narrowly pale yellowish; antennae brown, legs brown with yellowish tarsi. Head sub-quadrangular, with sub-rectilinear sides and narrowly rounded posterior angles. Eyes medium-sized and scarcely protruding. Surface of head with traces of transverse microstriation and scattered punctures. Pronotum sub-rectangular, longer than head, as wide as it, with almost rectilinear sides. Surface with dorsal series of 3 widely punctures and lateral series of 3 median punctures. Elytra sub-rectangular, moderately dilated posteriad, longer and wider than pronotum, with rounded humeral angles. Surface with very fine and scattered punctation, arranged in three series, one juxtasutural, one median and one lateral. Abdomen with traces of transverse micro-striation and very scattered, fine punctures.

Male unknown.

Etymology - The specific epithet refers to the type locality, as a noun in apposition.

DISTRIBUTION - The species is known only from the type locality.

REMARKS - This is the only species of Metolinus that I know with the uniformly dark body with narrowly yellowish pale posterior margin of elytra. Probably related to marginalis-group (BORDONI, 2002).

\section{Talliella laosiana Bordoni, 2013}

Material examined - N Laos, Phongsali prov., Boun Tai, 10 km SE, 1300-1500 m, Lao 16-25.V.2004, 2 exx. (cH), 1 ex. (cB).

Distribution - The species was described from the same locality of Laos (Phongsali).

\section{Sulawesina brendelli Bordoni, 2002}

Material examined - Sulawesi, Sulawesi Utara, Dumoga Bone N. P., P. Hornabrook XI.1985, 7 exx. (MMUE), 2 exx. (cB).

Distribution - The genus Sulawesina Bordoni, 2002 and the cited species seems endemic to Sulawesi (BORDONI, l. c.).

REMARKS - The specimens bear the label "Mitomorphus hornabrooki Last" (in litt.).

\section{Phacophallus flavipennis (Kraatz, 1859)}

MATERIAL EXAMINED - Sri Lanka, Dumballa env., 300 m, J. Kolibac 19.IV-9.V.1991, 1 ex. (NHMB); Malaysia, Cameron Highl., Y. Kiyoyama 24.II.1954, 1 ex. (cH).

Distribution - Indian, Indochinese and Indomalay subregions (BORDONI, 2002).

\section{Phacophallus japonicus (Cameron, 1933)}

Material exAmined - Cambodia, Pailin, $200 \mathrm{~m}$, S. Murzin 11-16.V.2009, 2 exx. (cS), 1 ex. (cB); W Sumatra, Talu, Simpangempat, Sukaminanti, W. Ullrich VII.1992, 4 exx. (NHMB), 1 ex. (cB).

Distribution - From Thailand to Bali and South China (Bordoni, 2002). New record for Cambodia.

\section{Erymus gracilis (Fauvel, 1895)}

Material examined - N Laos, Phongsali prov., Boun Tai, 10 km SE, 1300-1500 m, Lao 16-25.V.2004, 1 ex. (cH); N Laos, $20 \mathrm{~km}$ NW Louang, Namtha, $21^{\circ} 09.2 \mathrm{~N}$, $101^{\circ} 18.7 \mathrm{E}, 900 \pm 100 \mathrm{~m}$, E. Jendek \& O. Sausa 511.V.1997, 2 exx. (cH), 1 ex. (cB); Taiwan, Tai Chung Co., An Ma Shanm, 2 km Chun Lin, Li 24-26.VI.2003, 12 exx. (MNB), 2 exx. (cB).

Distribution - Widespread species, known from the Caspian area and from India to Sumba and South China (BORDONI, 2002), and Taiwan (Bordoni, 2011).

\section{Erymus tujuh sp. n.}

Material eXAmined - Holotype $\oint^{\Uparrow}$ : Sumatra, (Jambi), Gunung Tujuh, Kerinci N. P., 1700-1900 m, Bocak \& Bucakova 8.III.1991 (NHMB).

DESCRIPTION - Length of body $4.6 \mathrm{~mm}$; from anterior margin of head to posterior margin of elytra: $2.7 \mathrm{~mm}$. Body shiny, reddish brown with slightly darker head. Head ovoid, dilated anteriad, with rounded sides from eyes to the neck. Eyes medium-sized, very protruding. Surface of head with widely spaced, fine punctation. Pronotum dilated anteriad, moderately longer and narrower than head, with oblique anterior margins, rounded anterior angles and sinuate sides. Surface with dorsal series of 6 irregular punctures and lateral series of 3 anterior punctures. Elytra long, longer and wider than pronotum, dilated posteriad, with rounded humeral angles. Surface with superficial, spaced punctation, arranged in three series, one juxtasutural, one median and one lateral. Abdomen with fine punctation, arranged in two series on each segment.

Tergite (of peculiar shape) and sternite of the male genital segment as in Fig. I, 4-5. Aedeagus (Fig. I, 6) $0.77 \mathrm{~mm}$ long, ovoid elongate; parameres of peculiar shape; inner sac with distal portion covered with fine spinulae.

Etymology - The specific epithet refers to the type locality, as a noun in apposition.

DisTRIBUTION - The species is known only from the type locality.

REMARKS - This species differs from the congeners by the shape of tergite of the male genital segment, by the shape of parameres and by the inner sac of the aedeagus.

\section{Gyrohypnus maximus Bordoni, 2002}

Material examined - Taiwan, Tai Chung Co., An Ma Shanm, 2 km Chun Lin, Li 24-26.VI.2003, 1 ex. (MNB).

Distribution - The species seems endemic to Taiwan (BORDONI, 2002; 2011). 
Megalinus metallicus (Fauvel, 1895)

MATERIAL EXAMINED - “Indochine”, Jing Chay, Dassault 16.08, 1 ๙ (NHMB).

Distribution - In the Mountain areas from Pakistan to China and Taiwan (BORDONI, 2002).

Megalinus oculatus (Bordoni, 2002)

Material eXAmined - Taiwan, Tai Chung Co., An Ma Shan, 2 km Chun Lin, Li 24-26.VI.2003, 1 ex. (MNB).

Distribution - This species seems endemic to Taiwan (BORDONI, 2002).

\section{Emathidis humerosa (Bernhauer, 1934)}

Material EXAMined - C Vietnam, Tua Thien Hue prov., Bach Ma Nat. Park, surr. Hotel Morin, 1350-1400 m, 16.2N, 107.85E, L. Bartolozzi, G. Chelazzi, A. Bandinelli, S. Bambi \& F. Fabiani 23-28.V.2014, 1 ठै (MZF).

Distribution - This uncommon species was known until now only from China, Sichuan (Bordoni, 2003). The genus Emathidis Bordoni, 2007 (= Cibyra Bordoni, 2002, nom. preocc.) was described for the species dilucida Bordoni, 2002 from S Vietnam (Bao Loc) that differs from $E$. humerosa for the external characters and aedeagus. New record for Vietnam.

\section{Atopolinus ovaliceps (Scheerpeltz, 1965)}

MATERIAL EXAMINED - C Vietnam, Lam Dong prov., Lac Duong Distr., Bidoup Nuiba N. P., surr. Giamg Ly Ranger Station, 1420-1460 m, L. Bartolozzi, G. Chelazzi, S. Bambi, F. Fabiani, E. Orbach \& V. Sbordoni 16-21. VI.2015, 2 exx. (MZF), 1 ex. (cB).
Distribution - Distribution. Bhutan, North Myanmar, North Thailand, Malaysia, Yunnan and Guizhou (BordonI, 2002; 2006). New record for Vietnam.

Atopolinus phongsali Bordoni, 2013

Material exAmined -. N Laos, Phongsali env., 13001500 m, Lao 1-15.V.2004, 6 exx. (cH), 4 exx. (cB); Phongsali prov., Boun Tai, $10 \mathrm{~km} \mathrm{SE,} \mathrm{1100-1300} \mathrm{m,} \mathrm{Lao}$ 16-25.V.2004, 1 ex. (cB).

DISTRIBUTION - This species is known only from Laos.

\section{Atopolinus tanahrata sp. n.}

Material examined - Holotype $\widehat{\sigma}$ : Malaysia, W Pahang, Cameron Highl., Tanah Rata, 1500-1800 m, P. Pacholatko 2-26.III.2004 (NHMB).

DESCRIPTION - Length of body $9 \mathrm{~mm}$; from anterior margin of head to posterior margin of elytra: $6 \mathrm{~mm}$. Body shiny, reddish brown with yellowish humeral angles; antennae brown; legs pale yellowish. Head ovoid, with rounded sides from the eyes to the neck. Eyes mediumsized and scarcely protruding. Surface of head with very sparse punctation on the sides. Pronotum moderately longer and evidently wider than head, with very oblique anterior margins, obsolete anterior angles and sinuate sides. Surface with dorsal series of 7-8 fine punctures and lateral series of 4-5 widely, fine punctures. Elytra subquadrangular, a little dilated posteriad, slightly longer and evidently wider than pronotum, with rounded humeral angles. Surface with a series of broad, deep punctures near the suture, one median and one lateral. Abdomen with fine, sparse punctation on the sides.

Sixth visible male abdominal tergite (Fig. II, 1) and sternite (Fig. II, 2) with posterior median lobule; male genital segment (Fig. II, 3) with very small tergite; sternite

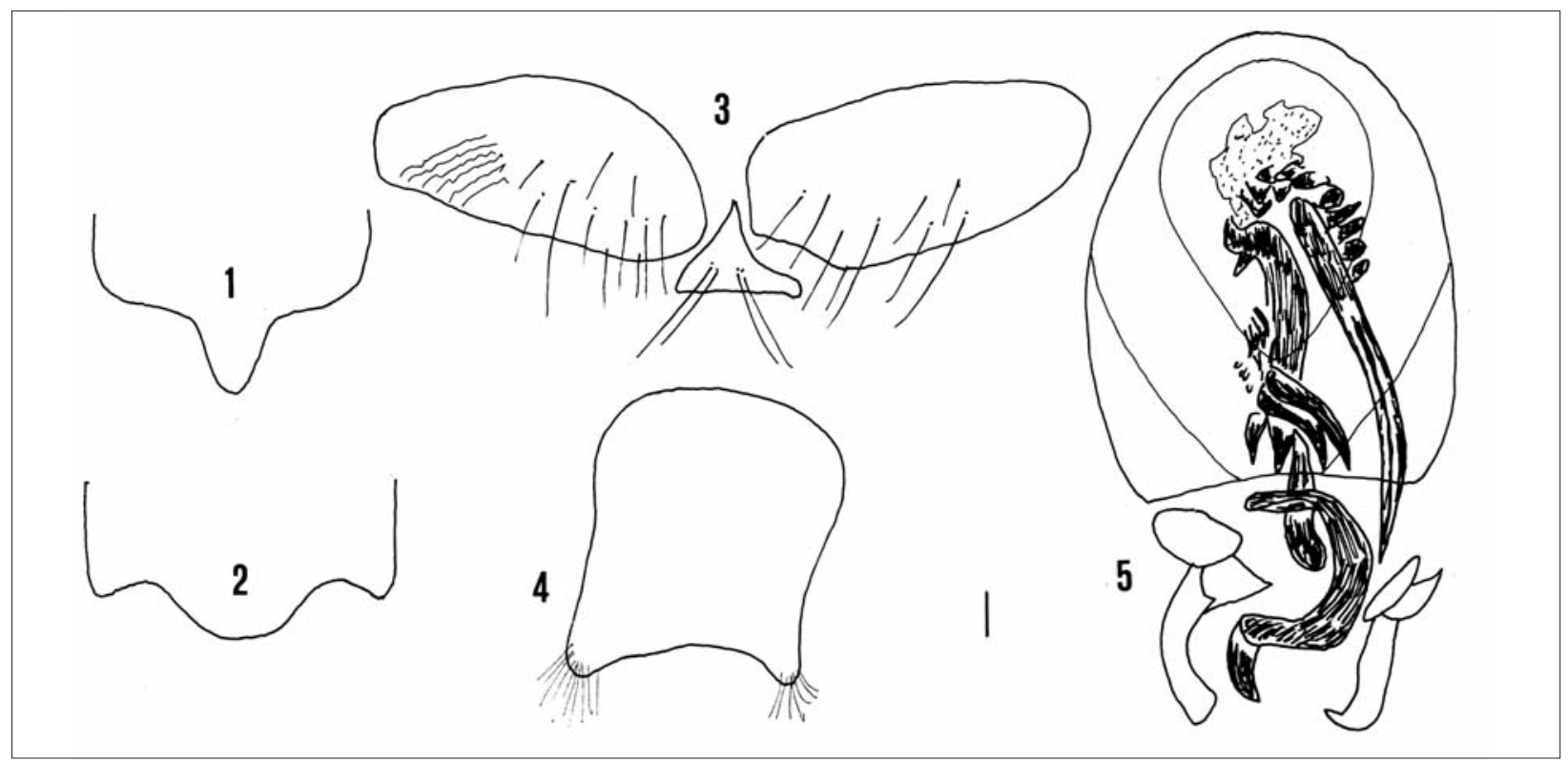

Fig. II -1 . Sixth male tergite, 2. $6^{\text {th }}$ male sternite, 3. male genital segment (enlarged), 4. sternite of the same, 5. aedeagus of Atopolinus tanahrata sp. n. (bar scale: $0.1 \mathrm{~mm}$ ). 
of the same type as in Fig. II, 4. Aedeagus (Fig. II, 5) 1.88 $\mathrm{mm}$ long, sub-ovoid, distally dilated, with asymmetrical, partially membranous pseudoparameres; inner sac with some large spines.

ETYMOLOGY - The specific epithet refers to the type locality, as a noun in apposition.

DISTRIBUTION - The species is known only from the type locality.

REMARKS - The new species differs from the congeners by the colour of the body and humeral angles, and especially by the structure of pseudoparameres and inner sac of the aedeagus.

\section{Atopolinus nigellus sp. $\mathrm{n}$.}

Material examined - Holotype $\delta^{\lambda}$ : N Vietnam, Vietnam-Laos border area, Quang Binh prov., $1 \mathrm{~km} \mathrm{~N}$ Cha

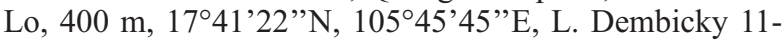
24.IV.2010 (NHMB); paratypes: same data, 3 ग, 9 ㅇ (NHMB), $3 \stackrel{\partial}{\partial}, 5$ (cB).
DESCRIPTION - Length of body $8.5 \mathrm{~mm}$; from anterior margin of head to posterior margin of elytra: $5 \mathrm{~mm}$. Body shiny, black with yellowish tarsi; antennae brown, long, slender, with $2^{\text {nd }}$ and $3^{\text {rd }}$ segments very long; the following short and narrow. Head sub-rectangular, moderately narrow anteriad, with rounded sides and broadly rounded posterior angles. Eyes small and almost flat. Surface of head with sparse punctation. Pronotum narrow, slender, much narrower and longer than head, with oblique anterior margins and strongly sinuate sides. Surface with dorsal series of 7 deep, fine punctures and lateral series of 4-5 finer punctures. Elytra broad, dilated posteriad, longer and much wider than pronotum, with rounded humeral angles. Surface with fine, not dense punctation, arranged in 5-6 series on elytra, apart the lateral margin without punctation. Abdomen with evident, long, yellowish pubescence and fine, dense punctation on the sides.

Sixth visible male tergite (Fig. III, 1) with short, median, posterior protrusion; $6^{\text {th }}$ visible sternite with concave posterior margin (Fig. III, 2); male genital segment with pleurae laterally provided with a long denticulation (Fig. III, 3); sternite of the same as in Fig. III, 4. Aedeagus (Fig. III, 5) $2.5 \mathrm{~mm}$ long, with asymmetrical, short pseudoparameres; inner sac with a series of short spines and two longer spines.

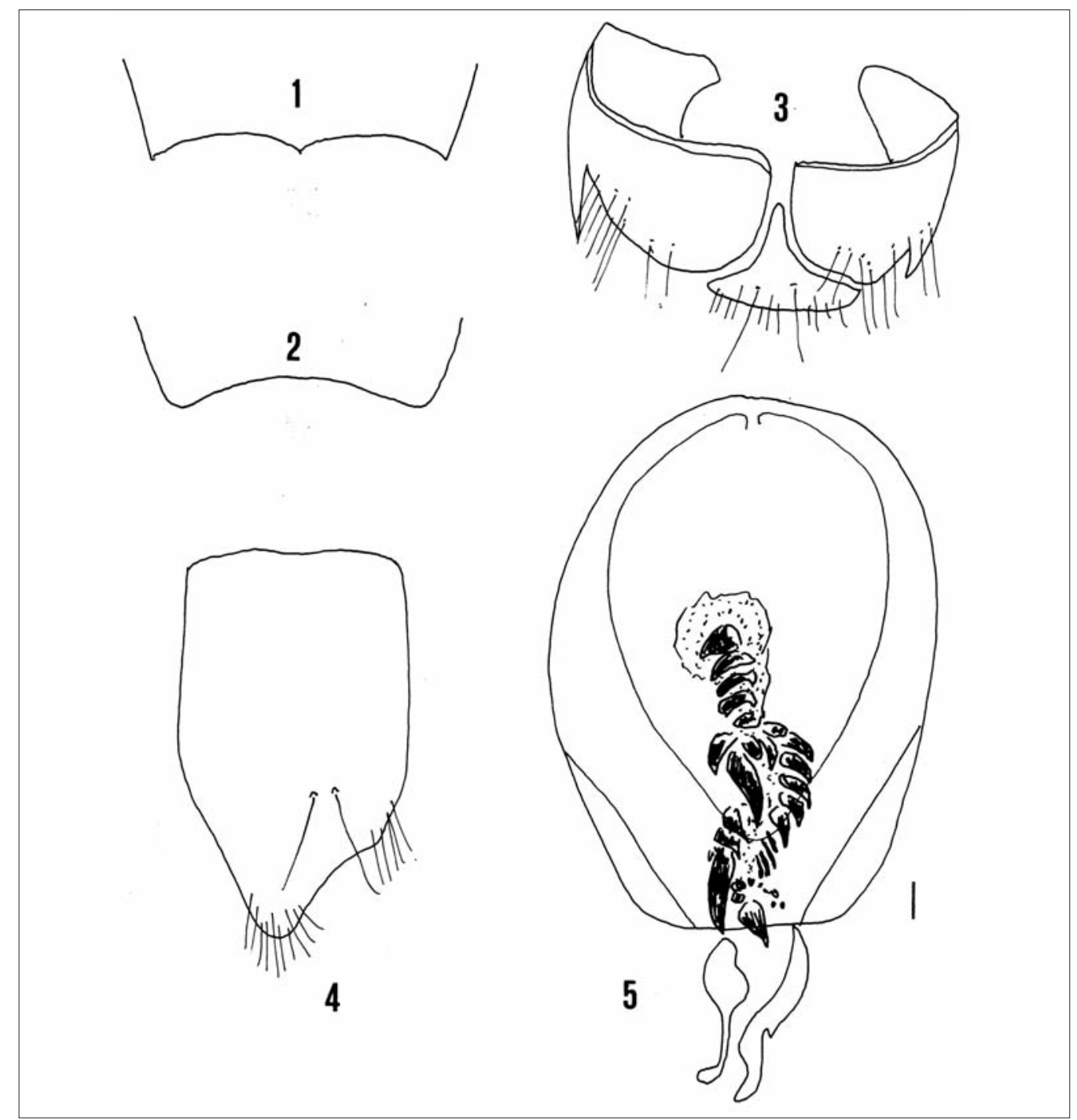

Fig. III -1 . Sixth male tergite, 2. $6^{\text {th }}$ male sternite, 3. male genital segment, 4. sternite of the same, 5 aedeagus of Atopolinus nigellus sp. n. (bar scale: $0.1 \mathrm{~mm}$ ). 
ETYMOLOGY - The specific epithet is the Latin nigellusa-um (black).

DISTRIBUTION - The species is known only from the type locality.

REMARKS - The new species differs from the congeners by the color of body and tarsi, by the shape of the $2^{\text {nd }}-3^{\text {rd }}$ antennomeres and especially by the genitalia.

\section{ACKNOWLEDGEMENTS}

I wish to thank the following colleagues for providing the material for this study; L. Bartolozzi (Museo Zoologico "La Specola", Firenze); M. Borer (Naturhistorisches Museum, Basel); Y. Hayashi (Kawanishi); T. Ito (Kyoto); D. Logunov (Manchester Museum, Manchester); A. Shavrin (Institute of Systematic Biology, Daugavpils); H. Schillhammer (Naturhistorisches Museum, Wien); M. Schülke (Berlin); M. Uhlig (Museum für Naturkunde, Berlin). Thanks also to two anonymous reviewers for their useful additional suggestions.

\section{REFERENCES}

Bernhauer M., 1934 - Siebenter Staphylinidenfauna von China - Entomologisches Nachrichtenblatt, Troppau, 8, 1: 1-20.

BordONI A., 2002 - Xantholinini della Regione Orientale (Coleoptera: Staphylinidae). Classificazione, filogenesi e revisione tassonomica - Memorie del Museo regionale di Scienze naturali, Torino, 33: $998 \mathrm{pp}$.

Bordoni A., 2003 - Contributo alla conoscenza degli Xantholinini delle Cina. II. (Coleoptera, Staphylinidae) - Fragmenta entomologica, 34, 2: 255-292.

Bordoni A., 2004 - Nuovi dati per la conoscenza degli Xantholinini della Regione Orientale. V. Daolus hromadkai gen. n., sp. n. del Nepal e Thyreocephalus perakensis sp. $n$. della Malesia (Coleoptera, Staphyinidae) - Entomologica, Bari, 38: 83-89.

Bordoni A. 2005 - Revision of the Xantholinini of Australia (Coleoptera: Staphylinidae) - Monografie del Museo regionale di Scienze naturali, Torino, 42: 435-614.

Bordoni A., 2006 - New data on the Xantholinini of the Oriental Region. XVI. Species from Myanmar, Thailand and Malaysia (Insecta: Coleoptera: Staphyinidae) Quaderno di Studi e Notizie di Storia Naturale della Romagna, 22: 119-127.

Bordoni A., 2007 - Notes on some Western Palaearctic Xantholinini (Coleoptera, Staphyinidae) - Zootaxa, 1431: 65-68.

Bordoni A., 2009 - Xantholinini della Cina, della Regione Orientale e dell'Australia. Nuove specie e nuovi dati geonemici (Coleoptera, Staphyinidae) - Fragmenta entomologica, 41, 1: 87-111.

BORDONi A., 2009a - New data on the species of the Xantholinini from the Oriental Region. XX. Species collected by Riedel in Sumatra, Java and Bali in 2005-
2007 (Coleoptera, Staphyinidae) - Carolinea, 67: 109115.

Bordoni A., 2010 - Revisione degli Xantholinini della Nuova Guinea e delle isole austromalesi (Coleoptera, Staphylinidae) - Bollettino del Museo regionale di Scienze naturali, Torino, 27, 2: 253-635.

Bordoni A., 2011 - New data and records on Xantholinini of Taiwan collected by Ales Smetana, with description of new species (Coleoptera, Staphylinidae) - Redia, 94: 2533.

Bordoni A., 2012 - New data on the Oriental Xantholinini. 26 $6^{\circ}$. Species of the Oxford Museum (Coleoptera, Staphylinidae) - Linzer biologische Beiträge, 44, 1: 421426.

Bordoni A., 2013 - New data on the Xantholinini from the Oriental Region. 32. New species and new records of North Laos in the collection Hayashi (Coleoptera, Staphylinidae) - Japanese Journal of systematic Entomology, 19, 2: 191-198.

Bordoni A., 2016 - New data on the Xantholinini of the Oriental Region. 38. New species and new records for Laos from the collections of the Naturhistorisches Museum, Basel (Coleoptera, Staphylinidae) - Entomologica Basiliensia et Collectionis Frey, 35: 133150.

Bordoni A., 2017 - New data on the Oriental Xantholinini. 40. New species and new records in the collection of Tateo Ito, Kyoto (Coleoptera, Staphylinidae) Redia, 100: 19-23. http://dx.doi.org/10.19263/REDIA100.17.03

Bordoni A., 2017 - New data on the Oriental Xantholinini. 41. New species and new records from Thailand (Insecta: Coleoptera: Staphylinidae) - Quaderno di Studi e Notizie di Storia Naturale della Romagna, 45: 87-95.

Cameron M., 1933 - New species of Staphylinidae (Col.) from Japan - The Entomologist's Montly Magazine, 69: 168-175.

CAMERon M., 1936 - New species of Staphyinidae (Col.) from the Malay Peninsula - Journal of the Federated Malay State Museums, 18: 40-53.

Cameron M., 1950 - New species of Staphyinidae (Col.) from the Malay Peninsula - Annals and Magazine of Natural History, 12, 3: 1-40.

Fauvel A., 1877 - Les Staphylinides de l'Australie et de la Polynésie - Annali del Museo civico di Storia naturale di Genova, 10: 168-297.

FAUVEl A., 1895 - Staphyinides nouveaux de l'Inde et de la Malaisie - Revue d'Entomologie: 180-286.

KraAtz G., 1859 - Die Staphylinen-Fauna von Ostindien, insbesondere der Insel Ceylan - Archiv der Naturgeschichte, 25, 1: 1-193.

Motschulsky V., 1858 - Enumération des nouvelles espèces des Coléoptères rapportés de ses voyages par M. Victor Motschulsky - Bulletin de la Société Impérial des Naturalistes de Moscou, 31, 3: 204-264.

SCHEERPELTZ O., 1965 - Wissenschaftliche Ergebnisse der Schwedischen Expedition 1934 nach Indien und Burma. Coleoptera Staphylinidae - Archiv für Zoologi, ser. 2, 7, 2: 93-371. 
136 - Blank Page 